\title{
An Effective Protocol for Proteome Analysis of Medaka (Oryzias latipes) after Acute Exposure to Ionizing Radiation
}

\author{
Yeni Pérez-Gélvez ${ }^{1, *(1)}$, Shem Unger ${ }^{2}$, Gerardo Gutiérrez-Sánchez ${ }^{3}$, Robert Bridger ${ }^{1}$, \\ Olin E. Rhodes Jr. ${ }^{4}$ and Carl Bergmann ${ }^{1}$ \\ 1 Complex Carbohydrate Research Center, The University of Georgia, Athens, GA 30602, USA \\ 2 Department of Biology, Wingate University, Wingate, NC 28174, USA \\ 3 Exact Sciences Laboratories, 145 E Badger Rd Suite 100, Madison, WI 53713, USA \\ 4 Savannah River Ecology Laboratory, The University of Georgia, Aiken, SC 29802, USA \\ * Correspondence: nataliap@uga.edu
}

Received: 11 June 2019; Accepted: 26 July 2019; Published: 30 July 2019

check for updates

\begin{abstract}
All terrestrial organisms are subject to evolutionary pressures associated with natural sources of ionizing radiation (IR). The legacy of human-induced IR associated with energy, weapons production, medicine, and research has changed the distribution and magnitude of these evolutionary pressures. To date, no study has systematically examined the effects of environmentally relevant doses of radiation exposure across an organismal proteome. This void in knowledge has been due, in part, to technological deficiencies that have hampered quantifiable environmentally relevant IR doses and sensitive detection of proteomic responses. Here, we describe a protocol that addresses both needs, combining quantifiable IR delivery with a reliable method to yield proteomic comparisons of control and irradiated Medaka fish. Exposures were conducted at the Savannah River Ecology Laboratory (SREL, in Aiken, SC), where fish were subsequently dissected into three tissue sets (carcasses, organs and intestines) and frozen until analysis. Tissue proteins were extracted, resolved by Sodium Dodecyl Sulfate-Polyacrylamide Gel Electrophoresis (SDS-PAGE), and each sample lane was divided into ten equal portions. Following in-gel tryptic digestion, peptides released from each gel portion were identified and quantified by Liquid Chromatography-Mass Spectrometry (LC-MS/MS) to obtain the most complete, comparative study to date of proteomic responses to environmentally relevant doses of IR. This method provides a simple approach for use in ongoing epidemiologic studies of chronic exposure to environmentally relevant levels of IR and should also serve well in physiological, developmental, and toxicological studies.
\end{abstract}

Keywords: in-gel digestion; ionizing radiation; medaka; Oryzias latipes; proteome

\section{Introduction}

Ionizing radiation (IR), from other than natural sources, has become an aspect of daily life over the course of the last century. While sites such as Fukushima and Chernobyl are well-known and well documented sources of exposure to radiation, there remain over 1000 locations within the United States alone that are contaminated with radiation and have yet to be sufficiently studied to fully understand the risk to human health and to the environment. Testing and manufacturing related to nuclear proliferation (for both energy and weapons) and rapid increases in the use of nuclear medicine [1], are becoming increasingly identified as sources of radionuclide contamination. Such contamination can have long lasting effects on public health and the environment, particularly in aquatic systems.

The effects of radionuclides on organisms can vary depending on the dose and exposure time and may result in changes in morphology and functional activity, both at the cellular and system levels. 
It is well documented, especially at high doses, that IR has detrimental effects on aquatic organisms. These include double-strand breaks (DSBs) and oxidative damage to DNA, genomic instability, alterations in RNA, proteins, and other metabolites, as well as bystander and transgenerational effects $[2,3]$. At low to intermediate doses of IR, proximal DSBs can lead to complex DNA damage, and have received heightened attention recently due to their correlation with cytotoxicity, increased risk of cancer, and mutagenesis [4-6]. Additionally, nontargeted effects (NTE), such as the bystander radiation response, low-dose hyper-radiosensitivity, and radiation-induced adaptive response may be present after low-dose exposure [7], confounding the interpretation of organismal responses to radiation [8]. Several studies in fish have demonstrated bystander effects in which a signal passed from a fish exposed to radiation to an unexposed fish induces responses in the recipient [9,10]. A recent study presented potential transgenerational bystander effects in fish and amphibian cells [11].

Organismal responses to IR include alterations in the expression and/or post-translational modifications of specific proteins in cells, tissues, and organic fluids such as serum, plasma, and urine [12-16]. However, it is unclear how these processes translate into the metabolic adaptations which underlie evolutionary change within species. Comparative proteomic studies strongly indicate that protein expression profiling is a vital tool for investigating responses of proteins of metabolic and structural importance subsequent to IR exposure. Proteomic profiling in model species exposed to elevated levels of IR, including mice, indicates numbers of significantly deregulated proteins. These proteins often are associated with metabolic processes, inflammatory responses, cytoskeletal structure, as well as various transcription factors $[15,17]$. Preliminary research using Medaka has detected proteomic changes following exposure to moderate to high levels of radiation, including significant alterations in the levels of proteins associated with DNA repair and cellular apoptosis [18].

The use of Medaka in genetics, biomedical, environmental, and ecotoxicological research has a long history [19-23]. Medaka is an ideal vertebrate species for proteomic studies due to its readily available genome sequence databases ( $800 \mathrm{Mb}),[24,25]$ which are vital to the successful interpretation of proteomic data. Protein expression profiling can identify significant changes in protein expression (biomarkers) associated with IR exposure level [26]. Transcriptomic analysis can provide similar information, but is blind to post-transcriptional and post-translational modifications of protein expression, which often produce metabolic adaptations of evolutionary consequence [27]. Therefore, proteomic analysis of Medaka to reveal responses and adaptations to environmentally relevant levels of IR not only contributes to our understanding of the potential health risks of low level IR exposure, but also serves to elucidate past evolutionary events and the future evolutionary potential of organisms.

The challenge, and the goal of this research, is to design an effective protocol for detecting relevant changes in proteins expressed in Medaka and other organisms exposed to IR. This paper presents such a protocol and provides another tool for analysis of acute or chronic exposure to environmental stressors.

\section{Experimental Design}

The methods described for this study provide a simple approach to detect proteomic responses to irradiation across different tissues (carcasses, organs and intestines) in Medaka. The in-gel digestion protocol described is an economical, easy, and reliable protocol that could be applied to other epidemiological studies with large sets of samples. We used the in-gel digestion method to compare proteins in control samples as well as samples irradiated at a moderate level (500 mGy), since previous research has shown that exposure to this level is high enough to induce detectable changes but low enough not to immediately kill fish $[9,28,29]$. Our goal was to ascertain the optimal protocol for assessing proteomic changes to environmentally relevant levels of IR by conducting an experiment with both sham control and $0.5 \mathrm{~Gy}$ of exposure. This comparative dataset provides a baseline for use in future physiological, developmental, and toxicological studies at levels of resolution that have previously been unattainable. This method uses state-of-the-art techniques to allow us to obtain robust results which we describe in detail as follows: (1) How exposure to moderate levels of IR was accomplished; (2) how to prepare samples for comparative analysis, including in-gel digestion; and (3) how the 
data were handled to obtain basic biological information. This protocol was developed for use in exploratory analysis after exposure to stressors such as IR. The results of this initial exploratory analysis also demonstrate the need for additional strategies to obtain a more detailed understanding of the organismal response.

\subsection{Materials}

- 12 wild-type adult Medaka ( 6-8 months old) with a body weight of $0.45+0.01 \mathrm{~g}$ and a $14 \mathrm{~h}: 10 \mathrm{~h}$ light-dark cycle at $25^{\circ} \mathrm{C}$;

- 4 liter of filtered water;

- Anesthetic solution: $250 \mathrm{mg} / \mathrm{L}$ of tricaine methane sulfonate (MS-222) (Fisher, Fair Lawn, NJ, USA; cat: NC0342409), buffered with sodium bicarbonate at or near to neutral $\mathrm{pH}$;

- Liquid nitrogen;

- Methanol HPLC grade (Sigma-Aldrich, St. Louis, MO, USA; Cat. no.: 34860-4L-R);

- Homogenizing solution kept at $4{ }^{\circ} \mathrm{C}$ : Mix chloroform (Fisher, Fair Lawn, NJ, USA; Cat. no.: C606SK-4), methanol, and Milli-Q water at ratio of 2:4:1.5, respectively;

- $\quad$ Acetone (Fisher, Fair Lawn, NJ, USA; Cat. no.: C606SK-4);

- Tris-HCl buffer: $1 \mathrm{mM}$ Tris base (Fisher Scientific, Fair Lawn, NJ, USA; Cat. no.: BP152-500), pH 7.2 and 2\% SDS (Sigma-Aldrich, St. Louis, MO, USA; Cat. no.: L4390);

- Pierce BCA protein assay kit (Thermo Scientific Pierce, Rockford, IL, USA; Cat. no.: 23227);

- Bolt 4-12\% Bis-Tris Plus gels (Thermo Scientific Pierce, Rockford, IL, USA; Cat. no.: NW04120BOX);

- Protein ladder (Thermo Scientific Pierce, Rockford, IL, USA; Cat. no.: LC5925);

- $\quad 2 \times$ Laemmli Sample Buffer (Bio-Rad, Hercules, CA, USA; Cat. no.: 1610737);

- Running buffer 1X: 50 mL of Bolt MOPS SDS running buffer (Thermo Scientific Pierce, Rockford, IL, USA; Cat. no.: B0001) mixed with $950 \mathrm{~mL}$ of deionized $\mathrm{H}_{2} \mathrm{O}(\mathrm{dH} 2 \mathrm{O})$;

- Plastic container $12 \times 8 \times 3 \mathrm{~cm}$, rinsed previously with $50 \%$ aqueous methanol twice and one time with $100 \%$ methanol;

- Instant Blue Coomassie (Expedeon, Cambridge, UK; Cat. no: ISB1L);

- Destaining solution: $50 \mathrm{~mL}$ methanol, $5 \mathrm{~mL}$ acetic acid (J.T Baker, Center Valley, PA, USA; Cat. no.: 9508-33) and $50 \mathrm{~mL} \mathrm{dH} 2 \mathrm{O}$;

- Isopropanol (Fisher, Fair Lawn, NJ, USA; Cat. no.: BP2635-4);

- Ambic solution: $0.158 \mathrm{~g}$ of ammonium bicarbonate (Sigma-Aldrich, St. Louis, MO, USA; Cat. no.: AG141-500G) dissolved in $20 \mathrm{~mL}$ of dH2O to obtain a $100 \mathrm{mM}$ solution;

- $\quad$ Acetonitrile HPLC grade (ACN) (Fisher, Fair Lawn, NJ, USA; Cat. no.: A988-4);

- $10 \mathrm{mM}$ dithiothreitol (DTT): $0.015 \mathrm{~g}$ of DTT (Research Products International, Mount Prospect, IL, USA; Cat. no.: D11000-25) dissolved in $10 \mathrm{~mL}$ of Ambic solution;

- $55 \mathrm{mM}$ iodoacetamide (IDA): $0.10 \mathrm{~g}$ of iodoacetamide (Sigma-Aldrich, St. Louis, MO, USA; Cat. no.: I1149-5G) dissolved in $10 \mathrm{~mL}$ of Ambic solution;

- Trypsin solution: $20 \mu \mathrm{g}$ of trypsin (Promega, Madison, WI, USA; Cat. no.: V5111) in $1 \mathrm{~mL}$ of cold Ambic solution. Final concentration $20 \mathrm{ng} / \mu \mathrm{L}$;

- Extraction solution: 50\% ACN / 50\% dH2O and 0.1\% formic acid (Sigma-Aldrich, St. Louis, MO, USA; Cat. no.: F0507-500mL);

- Buffer A $(0.1 \%$ aqueous formic acid);

- Buffer B (80\% ACN, $0.1 \%$ aqueous formic acid).

\subsection{Equipment}

- $\quad$ 1.5 L rectangular plastic containers (Pentair, Apopka, FL, USA; Cat. no.: PCt10);

- 1300 Ci Cs-137 source irradiator from the calibration facility at the Savannah River Nuclear Solutions (SRNS) (Aiken, SC, USA); 
- Pyrex petri dish $100 \times 10 \mathrm{~mm}$ (Sigma-Aldrich, St. Louis, MO, USA; Cat. no.: CLS3160100);

- Stainless steel disposable scalpels (Integra Miltex, York, PA, USA; Cat. no.: 4-411);

- Dressing forceps (Integra Miltex, York, PA, USA; Cat. no.: 18-184);

- Dumont \#3c forceps (Fine Science Tools, Foster city, CA, USA; Cat. no.: 11231-20;

- Clear zip bag, 3" $\mathrm{W} \times 4^{\prime \prime} \mathrm{H}, 2 \mathrm{~mL}$ (Action health, Bensenville, IL, USA; Cat. no.: 85251-85002;

- Stereo Microscope (Olympus, Shinjuku, Tokyo, Japan; Cat. no.: (model): SZ51);

- Mortar and pestle (CoorsTek, Golden, CO, USA; Cat. No.: 60316 and 60317);

- $5 \frac{3}{4}$ " disposable Pasteur borosilicate pipets (Fisher Scientific, Fair Lawn, NJ, USA; Cat. no.: 13-678-20B);

- Glass tube $16 \times 125 \mathrm{~mm}$ (Corning Incorporated, Corning, NY, USA; Cat. no.: 99447-16) rinsed twice with $50 \%$ aqueous $\mathrm{MeOH}$ and once with $100 \% \mathrm{MeOH}$;

- Vertical Rocker Roto-Shake Genie (Scientific Industries, Bohemia, NY, USA; Cat. no.: SI-1100),

- Allegra 6 refrigerated centrifuge (Beckman Coulter life sciences, Brea, CA, USA; Cat. no.: 366816);

- Heto vacuum centrifuge or speed vac (Heto-Holten A/S, Allerod, Denmark; Cat. no.: 23905B VR-maxi St.a.-1);

- Vortex Genie 2 (Fisher, Fair Lawn, NJ, USA; Cat. no: 12-812);

- Lyophilizer (Labconco corporation, Kansas City, MO, USA; Cat. no.: 7960040);

- Microcentrifuge tube pestle (USA Scientific Inc., Ocala, FL, USA; Cat. no.: 1415-5390), rinsed twice with $50 \% \mathrm{MeOH}$ and once with $100 \% \mathrm{MeOH}$;

- Mini Gel Tank (ThermoFisher Scientific, Rockford, IL, USA; Cat. no.: A25977);

- Horizontal rocker platform (Bellco Biotechnology, Vineland, NJ, USA; Cat. no.: 7740-10010);

- Ziploc bags quart freezer, $7^{\prime \prime} \mathrm{W} \times 7^{11} / 16^{\prime \prime} \mathrm{H}$ (S. C. Johnson \& Son, Inc. Racine, WI, USA);

- $\quad$ Glass and razor precleaned with Isopropanol $100 \%$ (see Note 2);

- New clean 1.7 mL Eppendorf tubes (MIDSCI, St. Louis, MO, USA; Cat. no.: AVSS1700);

- Heating module (Thermo Fisher Scientific, Rockford, IL, USA; Cat. no.: Pierce Reacti-Therm heating stirring module 18900);

- Incubator (Fisher, Pittsburgh, PA, USA; Cat. no.: 151030513);

- Nanosep 0.2 uM centrifugal filter units (PALL Life Sciences, NY, USA; Cat. no.: ODM02C34);

- Centrifuge (Beckman Coulter life sciences, Brea, CA, USA; Cat. no.: Microfuge 18);

- Glass crimp top vials (Thermo Fisher Scientific, Rockford, IL, USA; Cat. no: C4012-15), rinsed with $\mathrm{MeOH}$;

- $\quad$ Snap caps for glass vials (VWR, Rador, PA, USA; Cat. no.: 14235-494);

- HPLC Ultimate 3000 RSLCnano (ThermoFisher Scientific, San Jose, CA, USA; Cat. no.: ULTIM3000RSLCNANO) with a $15 \mathrm{~cm}$ C18 analytical PepMap column (Thermo Fisher Scientific, San Jose, CA, USA; Cat. no.: 160321);

- Orbitrap Fusion Tribrid mass spectrometer (Thermo Fisher Scientific, San Jose, CA, USA; Cat. no.: IQLAAEGAAPFADBMBCX).

\section{Procedures}

\subsection{Exposure to Radiation (Time for Completion: $48 \mathrm{~h}$ )}

1. Divide the fish into 2 groups: 6 adult fish for the control group and 6 for the treatment group.

2. Place each group in small plastic containers with $0.5 \mathrm{~L}$ of filtered water.

3. Expose the treatment group to ionizing radiation (0.5 Gy) at the Savannah River site calibration facility using a $1300 \mathrm{Ci}$ CS-137 source calibrated to a dose rate of $0.028 \mathrm{~Gy} /$ minute, for a total exposure of 17.9 min obtaining a total dose of $0.5 \mathrm{~Gy}$. An additional sham control group (no exposure) is subjected to the same protocol to account for handling stress.

4. After exposure fish are returned to the laboratory and kept in tanks for $24 \mathrm{~h}$. 


\subsection{Dissection (for 10 Fish $2-3 \mathrm{~h}$ )}

1. Euthanize the fish at $24 \mathrm{~h}$ post exposure according to the requirements of Animal Care and Use at the University of Georgia, AUP \#A201305-018-Y1-A0 part C: Experimental procedures: "Euthanasia of animals: Animals sacrificed for proteomic tissue research (or sick diseased fish) will be euthanatized by an overdose via immersion in anesthetic solution. A concentration of 250-500 mg/L (5-10 times the anesthetic dosage) is effective for Medaka according to AVMA 2013 guidelines [30]. Medaka will be left in the anesthetic solution for a minimum of $10 \mathrm{~min}$ after cessation of opercular movement. Tissues used for the radiation/proteomics study will be frozen in liquid nitrogen and stored at $-80^{\circ} \mathrm{C}$ until extracted for proteomics analysis. Euthanasia of animals will occur only at the Savannah River Ecology Laboratory". Note: The full AUP document can be found in the Supplementary Material File S1.

2. Place the fish into a glass petri dish (bottom or cover) and using a dissecting microscope open the fish with a scalpel, starting from the anus and continuing to the beginning of the head. Note: All the instruments and glassware must be clean, pre-washed with 50\% methanol twice and $100 \%$ methanol once in order to avoid contamination of the samples. Use of plastic should be avoided, as it may result in contamination of the tissues with phthalates, complicating the mass spectrometry analysis.

3. Using dressing forceps, open the ventral area of the fish and take out the kidney, heart, liver, and gonads and put together in a plastic zip bag previously labeled. This will be the organs group. CRITICAL STEP The tissues have to be keep on ice until they are frozen to avoid degradation and/or expression of proteins associated with death.

4. Separate the intestines and stomach and place in another zip bag, and finally place the carcass (muscle, brain, eyes, gills, spinal cord, fins, and scales) in a third plastic bag. Figure 1 shows a dissected Medaka highlighting the different tissue groups.

5. Using liquid nitrogen freeze all the tissues for 30-60 s. PAUSE STEP The samples are stored at $-80{ }^{\circ} \mathrm{C}$ until the next step.
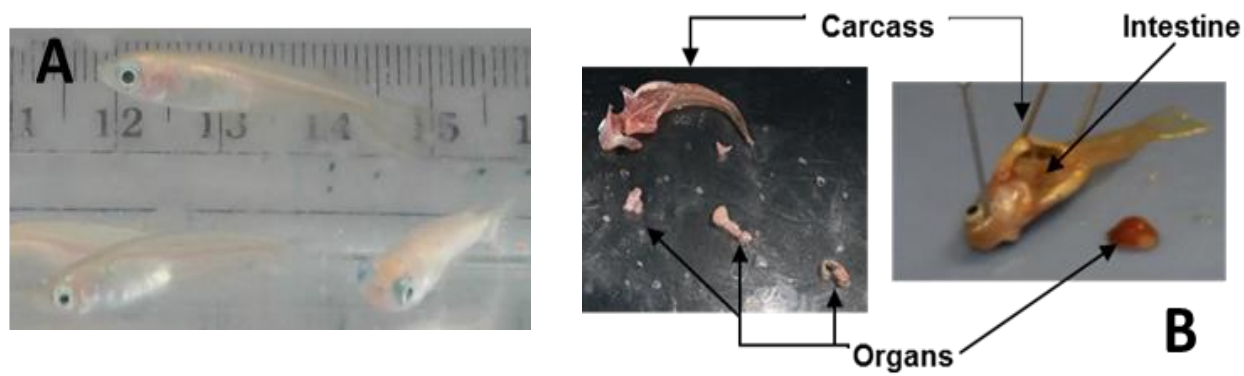

Figure 1. Medaka from the SREL facility. (A) Adult Medaka in a tank prior to the dissection and (B) dissected Medaka with arrows indicating carcass, organs, and intestines.

\subsection{Preparing Protein-Rich Powder (7 h)}

The tissues need to be delipidated and prepared for total protein analyses as described previously [31] with some modifications. Note: Starting at this point all glassware must be new, and pre-washed twice with $50 \%$ methanol and once with $100 \%$ methanol to avoid contaminants that will interfere during the mass spectrometry analysis.

1. In a mortar and pestle, add the sample and $3 \mathrm{~mL}$ of the homogenizing solution using glass Pasteur pipets and homogenize the tissue.

2. Transfer the homogenized sample into a $15 \mathrm{~mL}$ glass tube. Rinse the mortar and pestle with $3 \mathrm{~mL}$ of the homogenizing solution and add the rinse to the homogenized sample.

3. Allow the sample to incubate at room temperature on a vertical rocker for $3 \mathrm{~h}$. 
4. Centrifuge the sample for $15 \mathrm{~min}$ at $4{ }^{\circ} \mathrm{C}$ at $3500 \mathrm{rpm}$. CRITICAL STEP The centrifugation generates heat, and thus refrigeration is necessary to avoid degradation of proteins.

5. Decant the supernatant (glycosphingolipids) and, then, dry down the protein pellet using vacuum centrifugation for approximately 15-20 min. CRITICAL STEP Do not over dry. Over drying will result in an incomplete/difficult homogenization and can cause degradation of the samples. Note: If there is any interest in analyzing the glycosphingolipids, the supernatant from step 5 and 8 should be preserved in a pre-cleaned glass tube, dried under nitrogen, and kept at $-20{ }^{\circ} \mathrm{C}$ for further analyses.

6. Using Pasteur pipets, cover the sample in the bottom of the tube with homogenizing solution and incubate on the rocker for an additional $2 \mathrm{~h}$ at room temperature.

7. Centrifuge sample for $15 \mathrm{~min}$ at $4{ }^{\circ} \mathrm{C}$ at $3500 \mathrm{rpm}$.

8. Decant supernatant (glycosphingolipids) and, then, dry down the protein pellet using vacuum centrifugation.

9. Add $1 \mathrm{~mL}$ of cold $\left(4^{\circ} \mathrm{C}\right)$ Milli-Q water, and mix using the vortex. Add $4 \mathrm{~mL}$ of cold $\left(4^{\circ} \mathrm{C}\right)$ acetone, mix using the vortex, and incubate on ice for $15 \mathrm{~min}$.

10. Centrifuge sample for $15 \mathrm{~min}$ at $4{ }^{\circ} \mathrm{C}$ at $3500 \mathrm{rpm}$. Decant supernatant into waste and dry down the protein pellet.

11. Repeat steps 9-10.

12. Freeze protein powder $\left(-80^{\circ} \mathrm{C}\right)$ and lyophilize overnight.

13. Once dry, store protein powder at $-20^{\circ} \mathrm{C}$. PAUSE STEP the protein-rich powder can be keep at $-20^{\circ} \mathrm{C}$ for several months (In our case we have stored samples for up to 3 years with no significant change in the analyses). Note: the glass tubes have to be well capped to avoid humidity getting into the samples.

\subsection{SDS-Electrophoresis $(1.5 h)$}

1. Weigh 3-5 mg of protein-rich powder and resuspend with Tris- $\mathrm{HCl}$ buffer. Insoluble material is removed by centrifugation. Note: If necessary, use a microcentrifuge tube pestle before centrifugation to get a better homogenization of the sample. Prior to use, clean the pestle with $70 \%$ ethanol.

2. Determine the protein concentration using the Pierce BCA protein assay kit with bovine serum albumin as standard.

3. Prepare aliquots of $100 \mu \mathrm{g}$ of protein and dry under vacuum centrifugation.

4. Add $15 \mu \mathrm{L}$ of Milli-Q water to dissolve the dry sample and add the same volume of the $2 \times$ Laemmli Sample Buffer. Mix with the vortex and centrifuge. Note: The final volume cannot be more than $35 \mu \mathrm{L}$, this is due to the capacity of the loading wells being $40 \mu \mathrm{L}$. CRITICAL STEP Observe the color of the mix, if yellowish, add $2 \mu \mathrm{L} 100 \mathrm{mM} \mathrm{NaOH}$ at a time and mix until it turns blue. Mix using the vortex and centrifuge again.

5. Boil the samples for $5 \mathrm{~min}$ and then put the samples into a refrigerator set at $7{ }^{\circ} \mathrm{C}$ for $5 \mathrm{~min}$. Note: Be sure to cap the tubes well, or the sample will evaporate.

6. Add $10 \mu \mathrm{L}$ of protein ladder in the first well. Add protein samples leaving an empty well between samples, this will simplify cutting out the individual gel sections for the in-gel digestion step.

7. Run the gel at 200 volts for $30-60 \mathrm{~min}$.

8. Place the gel in a clean clear plastic container and add enough deionized water to cover it, swish back and forth 5 times. Pour out the water. Repeat the wash at least 3 times. Note: The plastic container must be dust and detergent free. It should be cleaned prior to use with $70 \%$ ethanol and allowed to dry.

9. Pour off the last water wash and add enough Instant Blue Coomasie stain to cover the gel, leave for $30 \mathrm{~min}$ to $1 \mathrm{~h}$ with gentle shaking. Note: Be sure that the gel can move freely in the staining solution to facilitate diffusion. Usually a $100 \mu \mathrm{g}$ of protein will stain well after $30 \mathrm{~min}$. 
10. Discard the stain solution and wash 2-3 times with deionized water.

11. PAUSE STEP Keep the gel in water inside a Ziploc bag until the next step to avoid the gel drying out.

\subsection{In-Gel Digestion (48 h after Full Distain of Gels Pieces)}

1. Place the gel on sanitized glass. Use a razor blade to remove top and bottom of the gel. Note: prior to use, clean the glass with 50\% methanol and 100\% methanol, and then one time with isopropanol, then, let it dry.

2. Carefully cut each lane sample run into 10 equally sized sections and then cut each section into smaller pieces $\left(1 \times 1 \mathrm{~mm}^{2}\right)$. Place all the gel pieces for each section into an Eppendorf tube. Note: Label the tube with sample and fraction information, i.e., control, fraction 5 can be CF5.

3. Add $500 \mu \mathrm{L}$ destaining solution to the gels and put on a rocker. Replace the solution 2-3 times during the day or let it rock overnight at room temperature. Repeat this until the gels are completely destained. NOTE: The time to completely destain the pieces of gel will depend on the frequency of changing the destaining solution, but $24 \mathrm{~h}$ is the fastest that the gel pieces can be destained.

4. Once that the gel pieces are completely destained, remove destaining solution from each tube, using a different tip for each tube, then add $150 \mu \mathrm{L}$ of HPLC grade water, and wait 5-10 min. Pull off water. Note: Starting at this point the tips and tubes used should be new and not been autoclaved, due to concerns of contamination that are detectable in the mass spectrometer.

5. Add $150 \mu \mathrm{L}$ of $30 \%$ aqueous $\mathrm{ACN}$ and wait 5-10 min. Pull off the solution. Repeat.

6. Add $150 \mu \mathrm{L}$ of Ambic solution, wait 5 min. Add $150 \mu \mathrm{L}$ ACN 100\% and wait 5-10 min. Pull off the solution.

7. Add $150 \mu \mathrm{L}$ ACN, wait 5-10 min. Pull off the solution. Samples are then dried under vacuum centrifugation (50-60 min).

8. PAUSE STEP Properly capped tubes containing dried gel pieces can be stored at room temperature until the next step.

9. Add $150 \mu \mathrm{L}$ of $100 \mathrm{mM}$ DTT, incubate at $65^{\circ} \mathrm{C}$ for $1 \mathrm{~h}$. Remove the samples from bath, let cool to room temperature and pull off the solution.

10. Add $150 \mu \mathrm{L}$ of $55 \mathrm{mM}$ iodoacetamide for $1 \mathrm{~h}$ at room temperature in the dark. Pull off the solution.

11. Wash gel pieces with $150 \mu \mathrm{L}$ of Ambic solution for 5-10 min. Add $150 \mu \mathrm{L} \mathrm{ACN,} \mathrm{wait} \mathrm{5-10} \mathrm{min.}$ Pull off the solution.

12. Dry the gels under vacuum centrifugation for 45-60 min.

\subsection{Tryptic Digestion $(20 \mathrm{~h})$}

1. Add trypsin solution 50:1 ww (protein/trypsin ratio) and, then, add enough Ambic to a final volume of $125 \mu \mathrm{L}$ to ensure that the dry gel pieces are completely submerged. Note: For $100 \mu \mathrm{g}$ of protein use $2 \mu \mathrm{g}$ of trypsin (100 $\mu \mathrm{L}$ of trypsin solution). To ensure a better distribution and absorption of trypsin into the gels, we mix $100 \mu \mathrm{L}$ of trypsin solution with $2.4 \mathrm{~mL}$ of Ambic to obtain a total of $2.5 \mathrm{~mL}(125 \mu \mathrm{L}$ per sample $\times 20$ samples $=2.5 \mathrm{~mL})$. Vortex and add $125 \mu \mathrm{L}$ of the mix.

2. Incubate over night at $37^{\circ} \mathrm{C}$ (maximum $18 \mathrm{~h}$ ).

3. After incubation, spin tubes, collect the supernatants and transfer each into a new prewashed tube (tube A). Change pipette tips between each tube.

4. Add $150 \mu \mathrm{L}$ of extraction solution to the tubes containing the gel pieces and wait 5 min. Transfer the liquid to a fresh set of tubes (tube A). Repeat these extractions two more times.

5. Transfer all the liquid from the set of tube A's to a set of Nanosep centrifugal filter units. Centrifuge at $12,000 \mathrm{rpm}$ for $15-30 \mathrm{~min}$. 
6. The filtrates, containing tryptic peptides, are then dried on a speed vacuum, usually overnight. The samples can be stored at $-20^{\circ} \mathrm{C}$ until MS analyses.

\subsection{LC-MS/MS Analysis of Tryptic Peptides (Mass Spectral Analysis) (8 h)}

1. Suspend the dried peptide in $19 \mu \mathrm{L}$ of buffer $\mathrm{A}$ and $1 \mu \mathrm{L}$ of buffer $\mathrm{B}$ and, then, transfer the dilute peptides into glass crimp top vials pre-cleaned with methanol $50 \%$ and $100 \%$.

2. Load the sample vials into the autosampler of an Ultimate 3000 LC System (Thermo Scientific Dionex).

3. Mass spectrometry parameters: Peptides are separated on a $15 \mathrm{~cm} \mathrm{C18} \mathrm{analytical} \mathrm{PepMap} \mathrm{Column}$ (Thermo Fisher Scientific) and eluted into an Orbitrap Fusion Tribrid mass spectrometer (Thermo Fisher Scientific) utilizing a nanoelectrospray ionization source via a 90 min gradient of increasing buffer B at a flow rate of approximately $200 \mathrm{~nL} / \mathrm{min}$. The gradient goes from $1 \%$ to $99 \%$ of buffer B between 3-60 $\mathrm{min}$ and holds at $99 \%$ for $5 \mathrm{~min}$, then, there is a ramp back down to $1 \%$ over $5 \mathrm{~min}$ and holding $1 \%$ for the last $20 \mathrm{~min}$ for equilibration. Full MS scans are acquired at $60 \mathrm{~K}$ resolution and MS2 scans following collision-induced dissociation are collected in the ion trap for the most intense ions in top-speed mode within a three second cycle using Fusion instrumentation software (version 4.1, Thermo Fisher Scientific). Dynamic exclusion is utilized to exclude precursor ions from the selection process for $60 \mathrm{~s}$ following a second selection within a $10 \mathrm{~s}$ window. We perform "blank-runs" (only buffer B) in between samples injections to ensure no carryover from sample to sample.

4. Results of the mass spectral analysis are in Raw format and are ready for the bioinformatics analysis that the user chooses. Below are summarized the bioinformatics and search options that we performed. Note: As an example, the raw data corresponding to the carcasses samples can be found in the public JPOST repository [32] under the Announced ID JPST000608.

\subsection{Database Searching and Protein Identification (6 h)}

1. Raw files obtained from the mass spectra analysis following each preparation/separation protocol were converted to mzXML files and then to $\mathrm{pkl}$ (peak list format) using Trans-Proteomic Pipeline Software (Seattle Proteome Center, Seattle, WA, USA). Each pkl file was searched for protein identification against concatenated database (normal and reverse database) containing proteins from the following species: Oryzias latipes and Dario rerio, from the Broad Institute and National Center for Biotechnology Information (NCBI) using MASCOT (Matrix Scientific, Boston, MA, USA). The reverse database is created by reversing all protein sequences from the target database using an in-house utility. Note: The concatenated fasta file can be found in the Supplementary Material File S2.

2. Mascot settings were as follows: tryptic enzymatic cleavages allowing for up to 2 missed cleavages, peptide tolerance of 20 parts-per-million, fragment ion tolerance of $0.5 \mathrm{Da}$, fixed modification due to carboxyamidomethylation of cysteine $(+57 \mathrm{Da})$, and variable modifications of oxidation of methionine $(+16 \mathrm{Da})$ and deamidation of asparagine or glutamine $(+0.98 \mathrm{Da})$. Note: the pkl and mascot files corresponding to all the tissue groups can be found in the public JPOST repository under the Announced ID JPST000608.

3. Proteins were organized and filtered using a $1 \%$ protein false discovery rate applied, minimum 2 peptides, and 40 score in proteins via ProteoIQ software (Provalt_3.1.12_03-21-18, NuSep, Bogart, GA, USA) to obtain a nonredundant list of homologous protein groups [33], by loading Mascot target and decoy search files into the software program. (See Table 1 in results sections for an example of the list of some identified protein in Carcasses). 
Table 1. Example of the outcome after the ProteoIQ filtering presenting the data for the top 30 proteins identified in carcasses.

\begin{tabular}{|c|c|c|c|c|c|c|c|c|c|c|c|}
\hline Sequence Id & Sequence Name & Gene & $\begin{array}{l}\text { Total } \\
\text { Score }\end{array}$ & $\begin{array}{c}\text { Total } \\
\text { Peptides }\end{array}$ & $\begin{array}{c}\text { Total } \\
\text { Spectra }\end{array}$ & $\begin{array}{l}\text { Control } \\
\text { Score }\end{array}$ & $\begin{array}{l}\text { Control } \\
\text { Peptides }\end{array}$ & $\begin{array}{c}\text { Control } \\
\text { Spectral } \\
\text { Count }\end{array}$ & $\begin{array}{l}\text { Treated } \\
\text { Score }\end{array}$ & $\begin{array}{l}\text { Treated } \\
\text { Peptides }\end{array}$ & $\begin{array}{r}\text { Treated } \\
\text { Spectra } \\
\text { Count }\end{array}$ \\
\hline gi|116062147|dbj|BAF34704.1| & $\begin{array}{l}\text { fast skeletal myosin heavy chain isoform } \\
\text { mMYH-7 [Oryzias latipes] }\end{array}$ & LOC110015468 & 7561.29 & 102 & 1935 & 7104.5 & 97 & 1061 & 5896.33 & 85 & 874 \\
\hline gi|116062139|dbj|BAF34700.1| & $\begin{array}{l}\text { fast skeletal myosin heavy chain isoform } \\
\text { mMYH-5 [Oryzias latipes] }\end{array}$ & LOC101163631 & 7442.38 & 100 & 1852 & 7069.86 & 96 & 1022 & 5726.27 & 82 & 830 \\
\hline gi|116062137|dbj|BAF34699.1| & $\begin{array}{c}\text { fast skeletal myosin heavy chain isoform } \\
\text { mMYH-6 [Oryzias latipes] }\end{array}$ & LOC111947749 & 7317.12 & 99 & 1755 & 6798.53 & 92 & 960 & 5818.96 & 84 & 795 \\
\hline gi|116062145|dbj|BAF34703.1| & $\begin{array}{l}\text { fast skeletal myosin heavy chain isoform } \\
\text { mMYH-3 [Oryzias latipes] }\end{array}$ & LOC101163661 & 6961.55 & 96 & 1640 & 6463.32 & 89 & 896 & 5464.79 & 80 & 744 \\
\hline gi|116062143|dbj|BAF34702.1| & $\begin{array}{l}\text { fast skeletal myosin heavy chain isoform } \\
\text { mMYH-2 [Oryzias latipes] }\end{array}$ & LOC101163414 & 6885.75 & 94 & 1697 & 6514.88 & 90 & 953 & 5332.89 & 78 & 744 \\
\hline gi|116062149|dbj|BAF34705.1| & $\begin{array}{l}\text { fast skeletal myosin heavy chain } \\
\text { mMYH-9 [Oryzias latipes] }\end{array}$ & LOC101163903 & 6816.79 & 92 & 1675 & 6449.61 & 88 & 933 & 5242.95 & 76 & 742 \\
\hline $\begin{array}{c}\text { gi|1174695518 } \\
\mid \text { ref|XP_020560645.1| }\end{array}$ & $\begin{array}{l}\text { myosin heavy chain, fast skeletal } \\
\text { muscle-like [Oryzias latipes] }\end{array}$ & LOC101163903 & 5923.87 & 82 & 1426 & 5592.76 & 78 & 811 & 4426.38 & 66 & 615 \\
\hline gi|116062151|dbj|BAF34706.1| & $\begin{array}{l}\text { fast skeletal myosin heavy chain isoform } \\
\text { mMYH-11 [Oryzias latipes] }\end{array}$ & LOC101164155 & 5713.97 & 77 & 1363 & 5411.98 & 74 & 779 & 4382.73 & 64 & 584 \\
\hline $\begin{array}{c}\text { gi|432868092 } \\
\text { |ref|XP_004071407.1| }\end{array}$ & $\begin{array}{c}\text { myosin heavy chain, fast skeletal muscle } \\
\text { [Oryzias latipes] }\end{array}$ & LOC101158198 & 5675.58 & 79 & 1400 & 5396.89 & 76 & 771 & 4490.4 & 65 & 629 \\
\hline gi|239735374|dbj|BAH70477.1| & $\begin{array}{l}\text { myosin heavy chain embryonic type } 1 \\
\text { [Oryzias latipes] }\end{array}$ & mmyhemb1 & 4594.2 & 64 & 1254 & 4369.27 & 62 & 703 & 3572.81 & 55 & 551 \\
\hline $\begin{array}{c}\text { gi|1040677427 } \\
\text { |ref|XP_017208743.1| }\end{array}$ & $\begin{array}{l}\text { myosin heavy chain, fast skeletal muscle } \\
\text { [Danio rerio] }\end{array}$ & LOC113076616 & 4293.4 & 60 & 1003 & 4122.75 & 59 & 574 & 3208.54 & 49 & 429 \\
\hline $\begin{array}{c}\text { gi|528483089 } \\
\mid \text { |ref|XP_001339206.5| }\end{array}$ & $\begin{array}{c}\text { myosin heavy chain, fast skeletal muscle } \\
\text { [Danio rerio] }\end{array}$ & myhb & 3651.99 & 51 & 839 & 3460.57 & 48 & 477 & 2656.29 & 42 & 362 \\
\hline gi|239735378|dbj|BAH70479.1| & $\begin{array}{c}\text { myosin heavy chain larval type } 2 \\
\text { [Oryzias latipes] }\end{array}$ & mmyhl2 & 3505.06 & 45 & 752 & 3270.63 & 44 & 422 & 2650.25 & 37 & 330 \\
\hline gi|239735376|dbj|BAH70478.1| & $\begin{array}{c}\text { myosin heavy chain larval type } 1 \\
\text { [Oryzias latipes] }\end{array}$ & mmyhl1 & 3434.68 & 44 & 767 & 3216.83 & 43 & 425 & 2614.22 & 37 & 342 \\
\hline gi|28422303|gb|AAH46881.1| & Zgc:66156 protein, partial [Danio rerio] & zgc:66156 & 3092.15 & 43 & 586 & 2917.85 & 42 & 340 & 2349.64 & 36 & 246 \\
\hline $\begin{array}{c}\text { gi|432864495 } \\
\text { |ref|XP_004070322.1| }\end{array}$ & $\begin{array}{l}\text { intermediate filament protein ON3-like } \\
\text { [Oryzias latipes] }\end{array}$ & LOC101167707 & 1287.9 & 21 & 120 & 1007.83 & 16 & 59 & 1107.19 & 18 & 61 \\
\hline $\begin{array}{c}\text { gi|432920251 } \\
\text { |ref|XP_004079911.1| }\end{array}$ & alpha-actinin-3 [Oryzias latipes] & actn3 & 1221.75 & 22 & 61 & 1108.52 & 20 & 44 & 286.58 & 6 & 17 \\
\hline $\begin{array}{c}\text { gi|11174681026 } \\
\text { |ref|XP_020566641.1| }\end{array}$ & $\begin{array}{c}\text { actin, alpha skeletal muscle isoform X1 } \\
\text { [Oryzias latipes] }\end{array}$ & acta1 & 1102.66 & 17 & 268 & 833.62 & 12 & 148 & 917.13 & 14 & 120 \\
\hline $\begin{array}{c}\text { gi|11746662893 } \\
\mid \text { |ref|XP_020566626.1| }\end{array}$ & myosin-7 [Oryzias latipes] & LOC100125526 & 1055.2 & 16 & 265 & 979.22 & 15 & 148 & 793.85 & 13 & 117 \\
\hline $\begin{array}{l}\text { gi|432895621 } \\
\text { |ref|XP_004076079.1| }\end{array}$ & creatine kinase M-type [Oryzias latipes] & LOC101166239 & 932.48 & 13 & 135 & 900.94 & 13 & 88 & 528.82 & 8 & 47 \\
\hline $\begin{array}{c}\text { gi|11746833558 } \\
\text { |ref|XP_020557031.1| }\end{array}$ & $\begin{array}{l}\text { vitellogenin } 1 \text { isoform X1 } \\
\text { [Oryzias latipes] }\end{array}$ & ol-vit1 & 903.99 & 14 & 71 & 712.57 & 11 & 29 & 647.26 & 10 & 42 \\
\hline $\begin{array}{c}\text { gi|1207193593 } \\
\mid \text { |ref|XP_021329509.1| }\end{array}$ & $\begin{array}{l}\text { actin, alpha cardiac muscle } 1 \text { [Danio } \\
\text { rerio] }\end{array}$ & LOC108941121 & 862.86 & 13 & 213 & 760.34 & 11 & 118 & 668.01 & 10 & 95 \\
\hline
\end{tabular}


Table 1. Cont.

\begin{tabular}{|c|c|c|c|c|c|c|c|c|c|c|c|}
\hline Sequence Id & Sequence Name & Gene & $\begin{array}{l}\text { Total } \\
\text { Score }\end{array}$ & $\begin{array}{c}\text { Total } \\
\text { Peptides }\end{array}$ & $\begin{array}{c}\text { Total } \\
\text { Spectra }\end{array}$ & $\begin{array}{l}\text { Control } \\
\text { Score }\end{array}$ & $\begin{array}{l}\text { Control } \\
\text { Peptides }\end{array}$ & $\begin{array}{c}\text { Control } \\
\text { Spectral } \\
\text { Count }\end{array}$ & $\begin{array}{l}\text { Treated } \\
\text { Score }\end{array}$ & $\begin{array}{l}\text { Treated } \\
\text { Peptides }\end{array}$ & $\begin{array}{r}\text { Treated } \\
\text { Spectra } \\
\text { Count }\end{array}$ \\
\hline $\begin{array}{c}\text { gi|432852666 } \\
\text { |ref|XP_004067324.1| }\end{array}$ & $\begin{array}{l}\text { tropomyosin alpha-1 chain isoform X1 } \\
\text { [Oryzias latipes] }\end{array}$ & LOC101164789 & 855.51 & 14 & 127 & 825.11 & 14 & 75 & 658.6 & 11 & 52 \\
\hline $\begin{array}{c}\text { gi|432922695 } \\
\text { |ref|XP_004080348.1| }\end{array}$ & $\begin{array}{l}\text { sarcoplasmic/endoplasmic reticulum } \\
\text { calcium ATPase } 1 \text { isoform X1 } \\
\text { [Oryzias latipes] }\end{array}$ & LOC101171864 & 821.21 & 13 & 96 & 575.85 & 8 & 46 & 630.84 & 11 & 50 \\
\hline gi|190338754|gb|AAI63562.1| & $\begin{array}{l}\text { Myosin, heavy polypeptide 6, cardiac } \\
\text { muscle, alpha [Danio rerio] }\end{array}$ & myh6 & 806.87 & 13 & 183 & 742.39 & 12 & 99 & 633.76 & 10 & 84 \\
\hline $\begin{array}{c}\text { gi|432864501 } \\
\text { |ref|XP_004070325.1| }\end{array}$ & $\begin{array}{l}\text { keratin, type II cytoskeletal 8-like } \\
\text { isoform X1 [Oryzias latipes] }\end{array}$ & LOC101168366 & 799.55 & 14 & 43 & 516.97 & 9 & 24 & 605.5 & 11 & 19 \\
\hline $\begin{array}{c}\text { gi|432847946 } \\
\text { |ref|XP_004066228.1| }\end{array}$ & $\begin{array}{c}\text { keratin, type I cytoskeletal 13-like } \\
\text { [Oryzias latipes] }\end{array}$ & LOC101159648 & 795.99 & 12 & 91 & 729.77 & 12 & 38 & 644.12 & 9 & 53 \\
\hline $\begin{array}{c}\text { gi|765137894 } \\
\text { |ref|XP_011480537.1| }\end{array}$ & creatine kinase M-type [Oryzias latipes] & LOC101163677 & 794.05 & 11 & 122 & 789.15 & 11 & 85 & 410.13 & 6 & 37 \\
\hline $\begin{array}{c}\text { gi|11746691476 } \\
\text { |ref|XP_020559720.1| }\end{array}$ & $\begin{array}{l}\text { tropomyosin alpha-1 chain } \\
\text { [Oryzias latipes] }\end{array}$ & LOC112151854 & 697.97 & 12 & 102 & 687.97 & 12 & 62 & 466.42 & 8 & 40 \\
\hline $\begin{array}{l}\text { gi|628601863 } \\
\text { |ref|NP_001278765.1| }\end{array}$ & $\begin{array}{c}\text { fructose-bisphosphate aldolase A } \\
\text { [Oryzias latipes] }\end{array}$ & aldoa & 697.38 & 9 & 133 & 622.22 & 8 & 68 & 593.27 & 9 & 65 \\
\hline
\end{tabular}

Score: Refers to either Mascot ion score, SEQUEST Xcorr, or tandem hyper score. Total protein score: Sums peptide score for all peptides matching to a protein. 


\subsection{Protein Functional Annotation}

Use the fasta sequence of each identified protein to obtain relevant biological information using the follow websites.

1. Gene Ontology terms are extracted from the Interpro and ProteoFun web sites (https://www.ebi. ac.uk/interpro/ and http://www.cbs.dtu.dk/services/ProtFun/).

2. Signal peptides in the deduced amino acid sequences are examined using the SignalP Web site (http://www.cbs.dtu.dk/services/SignalP/) and the SecretomeP 2.0 Web site (http://www.cbs.dtu. $\mathrm{dk} /$ services/SecretomeP/).

3. The family classification and functional category was obtained by using the pFam database (https://pfam.xfam.org/). (see Table 2 in results sections for an example of biological information of some proteins identified in carcasses).

\section{Results and Discussion}

Three tissue sets were harvested (carcasses, organs, and intestines) from control and treatment fish. Proteomic search parameters were set to require a minimum of two peptides for each protein identification, in order to minimize false positives [34]. A total of 993 proteins in the control sample and 1004 in the treated samples were identified in the present study. Figure 2 presents the distribution of the number of proteins detected, showing the common proteins in the different tissues tested, as well as those which were unique from the irradiated or control samples. In total there were 409,545 and 98 proteins in intestines, organs, and carcasses, respectively, that fulfilled the search parameters. From these, there were 106, 91, and nine proteins in intestines, organs, and carcasses, respectively, which were identified as unique to the treatment group and might represent a response to radiation. Across all proteins, 33 were uncharacterized, which implies that they have been experimentally documented but are not characterized in biochemical terms [35]. Future investigation of these proteins (unique and uncharacterized) may open a door to a better understanding of the effects of IR and possibly to the bystander effects that occur after exposure; this is an area of study which is largely unexploited.

a) Intestines

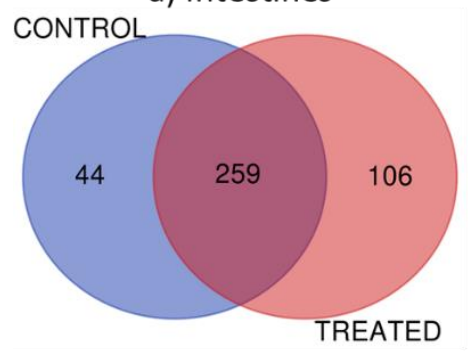

b) Organs

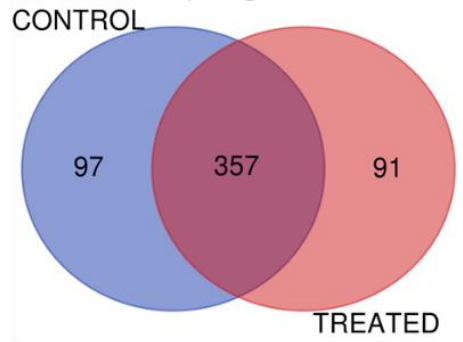

c) Carcasses

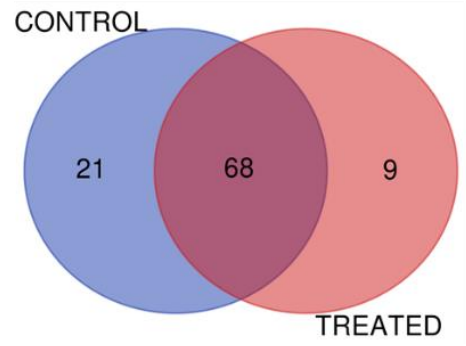

Figure 2. Venn diagram showing the number of identified proteins in Medaka. (a) Intestine with 409 total proteins identified, (b) organs with 545 identified proteins, and (c) carcasses with 98 identified proteins. 
An example of the results from ProteoIQ is presented in Table 1 and the ProteoIQ information for all the proteins identified are available in the Supplementary Tables S1-S3 for carcasses, intestines, and organs respectively. Our results suggest that the protocol presented in this was able to identify changes at the protein level and the data obtained represent a valuable starting point for further research. From here, the data analyses will depend on the purpose of the study. For example, the spectral counts obtained after filtering the data with ProteoIQ can be used to evaluate the levels of protein expression and compare the control versus the treated samples. Relative spectral counts can be used to identify upregulation or repression in comparison to control using, for example, the relative spectral abundance factor (RSAF) [36,37]. In the current dataset, we observed that organs and intestines are more likely to be affected by IR exposure than carcasses, since only 39 proteins present in carcasses have an increase or decrease in relative spectral counts two-fold or greater, as compared to 200 in intestines and 264 in organs. The functional annotation described in procedures Section 3.8 usually is applied to upregulated, downregulated, or unique proteins to provide insight into those processes that may be impacted by the stressor (biological information of the proteins with greater than or equal to two-fold change is presented in Supplementary Tables S4-S6). An example of the result from the bioinformatics search of some upregulated proteins is presented in the Table 2.

On the basis of the functional analysis (Supplementary Tables S4-S6), a few classes of proteins merit extra discussion due to their expression (up-/down-regulated) and/or high frequency of appearance in our results. Figure 3 shows two out of the four differentially expressed families discussed below. Sixteen proteins related to the EF-hand family exhibit a tissue-family dependent response to radiation. The EF-hand seven group showed repression in carcasses (two proteins only detected in control) but overexpression in organs (two proteins), while the EF-hand six group were repressed in intestines. Some proteins belonging to the EF-hand family can contribute to multiple processes like growth, cell motility, transcription, transduction, cell survival, and apoptosis [38], and are related with Alzheimer's disease, Downs Syndrome, and ALS [39]. Proteins belonging to the ribosomal family were detected in organs (27) and intestines (26) with varying expression; in intestine these proteins are 50\% repressed and $50 \%$ overexpressed, while in organs most of the ribosomal family proteins (21) are overexpressed. Ribosomal proteins can respond in different ways to IR exposure. Changes in the expression levels of proteins from this family as a result to exposure to IR have been reported [40,41], sometimes resulting in IR-sensitivity [42]. In addition, we detected proteins belonging to families that participate in dehydrogenase activity, such as Ldh, Aldedh, and ADH families. Proteins belonging to families with dehydrogenase function were repressed in treated organs but overexpressed in treated intestines. Previous studies have demonstrated that exposure to low and moderate levels of IR (0.02-1.0 Gy) reduces production of pyruvate dehydrogenase [14]. Reduction in enzymes like glucose 6-phosphate dehydrogenase increase the sensitivity to oxidative stress [43], which could increase sensitivity to IR. Our results suggest the same tendency toward repression of these families of proteins in treated organs. An increase in reactive oxygen species (ROS) in cells is a well know consequence after exposure to IR [44]. Lastly, 11 different proteins belonging to the Zona pellucida (ZP) family were overexpressed in our treated Medaka, mainly in the organs. The ZP domain is found in a variety of receptor-like eukaryotic glycoproteins that play fundamental roles in development, hearing, immunity, and cancer [45]. 

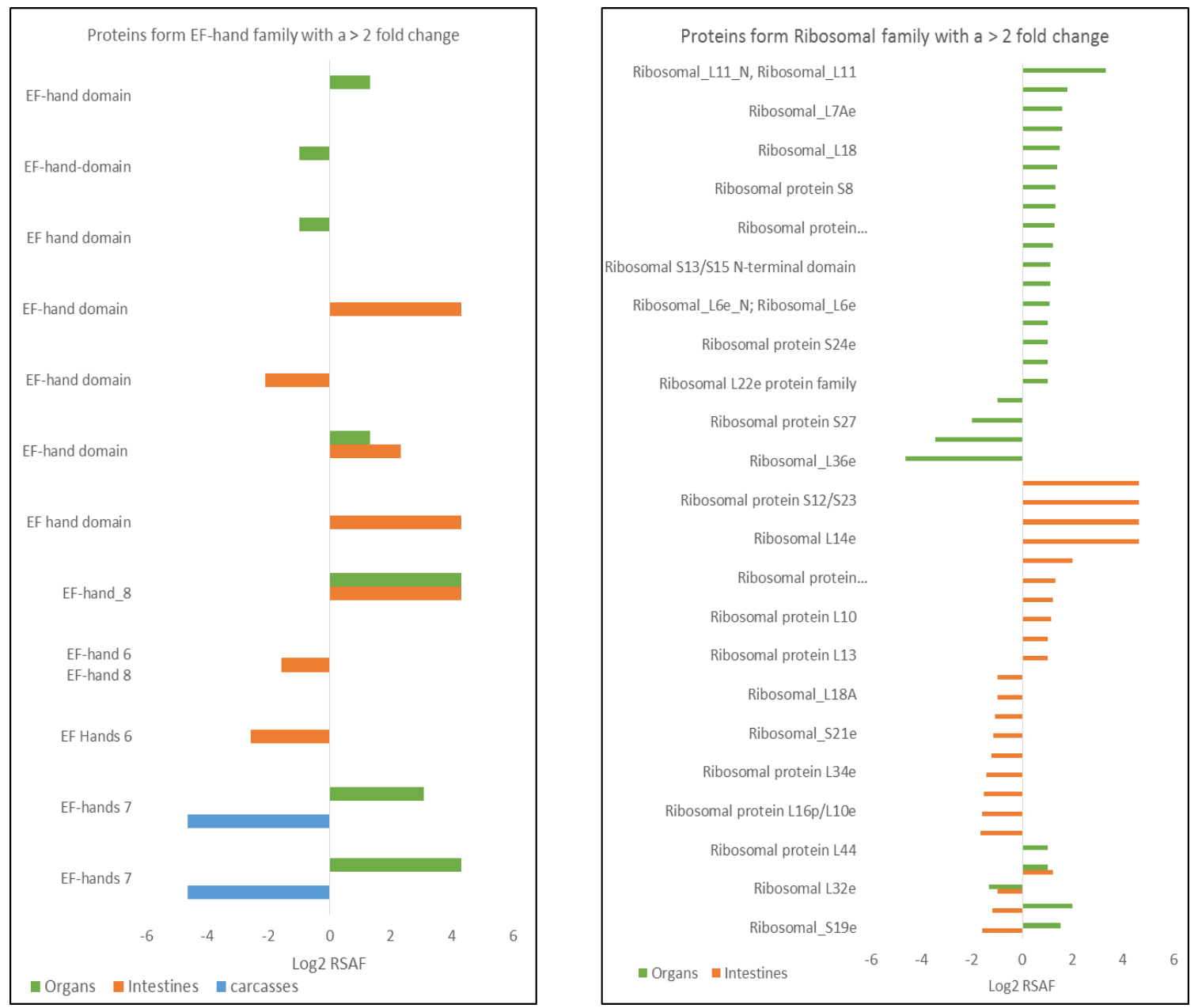

Figure 3. Histograms showing some proteins families with differential expression levels with $\geq 2$-fold change. For graphic purposes proteins that were detected only in one set of samples were assigned a relative spectral abundance factor (RSAF) of 25, and as result of $\log 2$ transformation is equal to 4.64. Proteins that were identified only in the control sample are presented as $-4.64\left(-\log _{2} 25\right.$.).

Our results demonstrate that our protocol identifies environmentally relevant IR-induced changes in the Medaka proteome. We detected members of several families of proteins that have been previously shown to respond to IR exposure, especially at high levels, providing us with additional confidence in our protocol's effectiveness and indicating that environmentally relevant exposures may mimic high level exposure in some regards. The detection of differentially expressed proteins after exposure to environmentally relevant levels of IR provides us with a clearer understanding of organismal responses and adaptations to radiation. Our findings indicate certain protein families that may be critical to our understanding of the biological response of Medaka to environmentally relevant doses of IR, and they are likely candidates for future research in radiation biomarkers. Finally, the protocol presented here will enable studies of whole body response to IR and uncover trending expression changes during the course of chronic exposure to IR, ultimately leading to a more comprehensive understanding of the molecular and systemic impacts of IR. 
Table 2. Biological information of some overexpressed proteins detected in Medaka organs after acute exposure to IR.

\begin{tabular}{|c|c|c|c|c|c|c|c|c|c|c|}
\hline Sequence Id & Sequence Name & Gene & $\begin{array}{l}\text { RATIO } \\
\text { RSAF }\end{array}$ & pFAM & Secretome & Signal IP & Score & $\begin{array}{l}\text { Biological Process } \\
\text { Involve in }\end{array}$ & $\begin{array}{c}\text { Molecular } \\
\text { Function Enables }\end{array}$ & $\begin{array}{c}\text { Cellular } \\
\text { Component Part of }\end{array}$ \\
\hline $\begin{array}{l}\text { gi||1174671686 } \\
\mid \text { |ref|XP_004080935.3| }\end{array}$ & $\begin{array}{l}\text { LOW QUALITY } \\
\text { PROTEIN: } \\
\text { Ras-related } \\
\text { protein Rab-18 } \\
\text { [Oryzias latipes] }\end{array}$ & rab18 & NC & Ras family & 0.377 & 0.118 & NO & NP & $\begin{array}{l}3924 \text { GTPase } \\
\text { activity } 5525 \text { GTP } \\
\text { binding }\end{array}$ & NP \\
\hline $\begin{array}{c}\text { gi|765158221 } \\
\mid \text { |ref|XP_011488823.1| }\end{array}$ & $\begin{array}{c}\text { uncharacterized } \\
\text { protein } \\
\text { LOC101162088 } \\
\text { [Oryzias latipes] }\end{array}$ & LOC101162088 & NC & $\begin{array}{l}\text { Zona } \\
\text { pellucida-like } \\
\text { domain }\end{array}$ & 0.535 & 0.735 & YES & $\begin{array}{l}\text { GO:2000344 positive } \\
\text { regulation of } \\
\text { acrosome reaction } \\
\text { GO:0005803 egg coat } \\
\text { formation } \\
\text { GO:0007339 binding } \\
\text { of sperm to zona } \\
\text { pellucida }\end{array}$ & $\begin{array}{l}\text { GO:0032190 } \\
\text { acrosin binding }\end{array}$ & NP \\
\hline $\begin{array}{l}\text { gi||1174681297 } \\
\text { |ref|XP_020567346.1| }\end{array}$ & $\begin{array}{l}\text { 60S ribosomal } \\
\text { protein L12 } \\
\text { [Oryzias latipes] }\end{array}$ & rpl12 & 10 & $\begin{array}{c}\text { Ribosomal_L11_N, } \\
\text { Ribosomal_L11 }\end{array}$ & 0.853 & 0.331 & NO & $\begin{array}{l}\text { GO:0006412 } \\
\text { translation }\end{array}$ & $\begin{array}{l}\text { GO:0003735 } \\
\text { structural } \\
\text { constituent of } \\
\text { ribosome }\end{array}$ & $\begin{array}{l}\text { GO:0005840 } \\
\text { ribosome }\end{array}$ \\
\hline $\begin{array}{c}\text { gi||765151708 } \\
\mid \text { |ref|XP_011486186.1| }\end{array}$ & $\begin{array}{c}\text { parvalbumin } \\
\text { beta-like } \\
\text { [Oryzias latipes] }\end{array}$ & LOC101173896 & 8.5 & EF-hands 7 & 0.328 & 0.176 & NO & NP & $\begin{array}{c}\text { GO:0005509 } \\
\text { calcium ion } \\
\text { binding } \\
\text { GO:0046872 metal } \\
\text { ion binding }\end{array}$ & $\begin{array}{c}\text { GO:0005737 } \\
\text { cytoplasm } \\
\text { GO:0005634 nucleus }\end{array}$ \\
\hline $\begin{array}{c}\text { gi|157278241 } \\
\text { |ref|NP_001098220.1| }\end{array}$ & $\begin{array}{c}\text { ZPC domain } \\
\text { containing protein } \\
4 \text { precursor } \\
\text { [Oryzias latipes] }\end{array}$ & LOC100049336 & 5.33333 & zona pellucida & 0.721 & 0.659 & YES & $\begin{array}{c}\text { GO:0007339 binding } \\
\text { of sperm to zona } \\
\text { pellucida } \\
\text { GO:0035803 egg coat } \\
\text { formation } \\
\text { GO:2000344 positive } \\
\text { regulation of } \\
\text { acrosome reaction }\end{array}$ & $\begin{array}{c}\text { GO:0035804 } \\
\text { structural } \\
\text { constituent of egg } \\
\text { coat } \\
\text { GO:0032190 } \\
\text { acrosin binding }\end{array}$ & NP \\
\hline $\begin{array}{l}\text { gi||1174689816 } \\
\mid \text { ref|XP_011474004.2| }\end{array}$ & $\begin{array}{c}60 \mathrm{~S} \text { ribosomal } \\
\text { protein L22-like } \\
\text { [Oryzias latipes] }\end{array}$ & LOC101166956 & 3.5 & Ribosomal_L22e & 0.75 & 0.128 & NO & $\begin{array}{c}\text { GO:0033077 T cell } \\
\text { differentiation in } \\
\text { thymus } \\
\text { GO:0006412 } \\
\text { translation }\end{array}$ & $\begin{array}{c}\text { GO:0003723 RNA } \\
\text { binding } \\
\text { GO:0003735 } \\
\text { structural } \\
\text { constituent of } \\
\text { ribosome }\end{array}$ & $\begin{array}{l}\text { GO:0005840 } \\
\text { ribosome }\end{array}$ \\
\hline
\end{tabular}


Table 2. Cont.

\begin{tabular}{|c|c|c|c|c|c|c|c|c|c|c|}
\hline Sequence Id & Sequence Name & Gene & $\begin{array}{l}\text { RATIO } \\
\text { RSAF }\end{array}$ & pFAM & Secretome & Signal II & Score & $\begin{array}{l}\text { Biological Process } \\
\text { Involve in }\end{array}$ & $\begin{array}{c}\text { Molecular } \\
\text { Function Enables }\end{array}$ & $\begin{array}{c}\text { Cellular } \\
\text { Component Part of }\end{array}$ \\
\hline $\begin{array}{c}\text { gi|432867558 } \\
\text { |ref|XP_004071242.1| }\end{array}$ & $\begin{array}{c}\text { cytochrome c } \\
\text { oxidase subunit } \\
\text { NDUFA4 } \\
\text { [Oryzias latipes] }\end{array}$ & LOC101155111 & 3 & B12D & 0.884 & 0.239 & NO & $\begin{array}{l}\text { GO:0002290 electron } \\
\text { transport chain } \\
\text { GO:1902600 proton } \\
\text { transmembrane } \\
\text { transport }\end{array}$ & $\begin{array}{c}\text { GO:0004129 } \\
\text { cytochrome-c } \\
\text { oxidase activity }\end{array}$ & $\begin{array}{c}\text { GO:0016020 } \\
\text { membrane } \\
\text { GO:0016021 integral } \\
\text { component of } \\
\text { membrane } \\
\text { GO:0005751 } \\
\text { mitochondrial } \\
\text { respiratory chain } \\
\text { complex IV }\end{array}$ \\
\hline $\begin{array}{c}\text { gi|765145559 } \\
\text { |ref|XP_004077973.2| }\end{array}$ & $\begin{array}{c}\text { 60S ribosomal } \\
\text { protein L18 } \\
\text { [Oryzias latipes] }\end{array}$ & rpl18 & 2.8 & Ribosomal_L18 & 0.614 & 0.202 & NO & $\begin{array}{l}\text { GO:0006412 } \\
\text { translation }\end{array}$ & $\begin{array}{c}\text { GO:0003735 } \\
\text { structural } \\
\text { constituent of } \\
\text { ribosome }\end{array}$ & $\begin{array}{l}\text { GO:0005840 } \\
\text { ribosome }\end{array}$ \\
\hline $\begin{array}{c}\text { gi|1174693985 } \\
\text { |ref|XP_020560297.1| }\end{array}$ & $\begin{array}{c}\text { myosin light } \\
\text { polypeptide } 6 \\
\text { isoform X1 } \\
\text { [Oryzias latipes] }\end{array}$ & LOC101167617 & 2.5 & EF-hand domain & 0.4 & 0.106 & NO & NP & $\begin{array}{l}\text { GO:0005509 } \\
\text { calcium ion } \\
\text { binding }\end{array}$ & NP \\
\hline $\begin{array}{c}\text { gi|182889290 } \\
\text { |gb|AAI64893.1| }\end{array}$ & $\begin{array}{l}\text { Calm1b protein } \\
\text { [Danio rerio] }\end{array}$ & calm1 & 2.5 & EF-hand domain & 0.676 & 0.101 & NO & $\begin{array}{c}\text { GO:0019722 } \\
\text { calcium-mediated } \\
\text { signaling }\end{array}$ & $\begin{array}{l}\text { GO:0005509 } \\
\text { calcium ion } \\
\text { binding } \\
\text { GO:0046872 metal } \\
\text { ion binding }\end{array}$ & $\mathrm{NP}$ \\
\hline $\begin{array}{c}\text { gi|1174655990 } \\
\text { |ref|XP_020564957.1| }\end{array}$ & $\begin{array}{l}\text { uncharacterized } \\
\text { protein } \\
\text { LOC101172014 } \\
\text { isoform X2 } \\
\text { [Oryzias latipes] }\end{array}$ & LOC110014571 & 2.27273 & NP & 0.896 & 0.814 & YES & $\mathrm{NP}$ & NP & NP \\
\hline $\begin{array}{c}\text { gi|765142574 } \\
\text { |ref|XP_011482440.1| }\end{array}$ & $\begin{array}{l}\text { uncharacterized } \\
\text { protein } \\
\text { LOC101162625 } \\
\text { isoform X2 } \\
\text { [Oryzias latipes] }\end{array}$ & LOC101162625 & 2.26667 & NP & 0.687 & 0.738 & YES & $\mathrm{NP}$ & NP & $\mathrm{NP}$ \\
\hline
\end{tabular}

NC: not detected in control NP: not predicted. 
Supplementary Materials: The following are available online at http://www.mdpi.com/2409-9279/2/3/66/s1, Table S1: Proteins identified in Carcasses in control and treated samples. Table S2: Proteins identified in Intestines in control and treated samples. Table S3: Proteins identified in Organs in control and treated samples. Table S4. Proteins with $\mathrm{a} \geq 2$ Fold change identified in Carcasses. Table S5 Proteins with a $\geq 2$ Fold change identified in Intestines. Table S6. Proteins with a $\geq 2$ Fold change identified in Carcasses. File S1: Animal Care and Use at the University of Georgia, AUP \#A201305-018-Y1-A0. File S2: concatenated fasta file.

Author Contributions: All authors conceived and designed the experiments methodology; Y.P.-G., S.U., G.G.-S., and R.B., performed the experiments; Y.P.-G. analyzed and validated the data; Y.P.-G. and S.U. wrote the manuscript; O.E.R.J. and C.B. funding acquisition; all the authors reviewed the manuscript.

Funding: This research was supported through funding from the U.S. Department of Energy under Award Number DE-EM0004391 to the University of Georgia Research Foundation.

Acknowledgments: We thank the Savannah River site calibration facility for conducting the exposure for this experiment. The authors thank the students that assisted in the lab during this research: Jason Moraczewski, Jerin Varghese, and Joel Hyder for handling the samples. Linda Chinelo Egbosiuba, Olivia Gavriella Mendel, Anand Shah, and Shane Mohsin for searching the proteins biological information in the web searchers. Tova Asher and Matthew William Wright for their help on the creation of the data base.

Conflicts of Interest: The authors declare no conflict of interest. The funding sponsors had no role in the design of the study; in the collection, analyses, or interpretation of data; in the writing of the manuscript, and in the decision to publish the results.

\section{References}

1. UNSCEAR. Sources and Effects of Ionizing Radiation. Report to the General Assembly with Scientific Annexes; Nations, U., Ed.; United Nations Scientific Committee on the Effects of Atomic Radiation Vienna: New York, NY, USA, 2008; Volume 1, p. 221.

2. Reisz, J.A.; Bansal, N.; Qian, J.; Zhao, W.; Furdui, C.M. Effects of ionizing radiation on biological molecules-mechanisms of damage and emerging methods of detection. Antioxid. Redox Signal. 2014, 21, 260-292. [CrossRef] [PubMed]

3. Dubrova, Y.E. Radiation-induced transgenerational instability. Oncogene 2003, 22, 7087-7093. [CrossRef] [PubMed]

4. Goodhead, D.T. Initial events in the cellular effects of ionizing radiations: Clustered damage in DNA. Int. J. Radiat. Biol. 1994, 65, 7-17. [CrossRef] [PubMed]

5. Mavragani, I.V.; Nikitaki, Z.; Souli, M.P.; Aziz, A.; Nowsheen, S.; Aziz, K.; Rogakou, E.; Georgakilas, A.G. Complex DNA Damage: A Route to Radiation-Induced Genomic Instability and Carcinogenesis. Cancers 2017, 9, 91. [CrossRef] [PubMed]

6. Magnander, K.; Elmroth, K. Biological consequences of formation and repair of complex DNA damage. Cancer Lett. 2012, 327, 90-96. [CrossRef]

7. Desouky, O.; Ding, N.; Zhou, G.M. Targeted and non-targeted effects of ionizing radiation. J. Radiat. Res. Appl. Sci. 2015, 8, 247-254. [CrossRef]

8. Mothersill, C.; Seymour, C. Radiation-induced bystander and other non-targeted effects: Novel intervention points in cancer therapy? Curr. Cancer Drug Targets 2006, 6, 447-454. [CrossRef]

9. Mothersill, C.; Bucking, C.; Smith, R.W.; Agnihotri, N.; Oneill, A.; Kilemade, M.; Seymour, C.B. Communication of radiation-induced stress or bystander signals between fish in vivo. Environ. Sci. Technol. 2006, 40, 6859-6864. [CrossRef]

10. Smith, R.W.; Mothersill, C.; Hinton, T.; Seymour, C.B. Exposure to low level chronic radiation leads to adaptation to a subsequent acute $\mathrm{X}$-ray dose and communication of modified acute $\mathrm{X}$-ray induced bystander signals in medaka (Japanese rice fish, Oryzias latipes). Int. J. Radiat. Biol. 2011, 87, 1011-1022. [CrossRef]

11. Vo, N.T.K.; Seymour, C.B.; Mothersill, C.E. Radiobiological characteristics of descendant progeny of fish and amphibian cells that survive the initial ionizing radiation dose. Environ. Res. 2019, 169, 494-500. [CrossRef]

12. Xie, A.; Odate, S.; Chandramouly, G.; Scully, R. H2AX post-translational modifications in the ionizing radiation response and homologous recombination. Cell Cycle 2010, 9, 3602-3610. [CrossRef] [PubMed]

13. Chaze, T.; Slomianny, M.-C.; Milliat, F.; Tarlet, G.; Lefebvre-Darroman, T.; Gourmelon, P.; Bey, E.; Benderitter, M.; Michalski, J.-C.; Guipaud, O. Alteration of the Serum N-glycome of Mice Locally Exposed to High Doses of Ionizing Radiation. Mol. Cell. Proteom. 2013, 12, 283-301. [CrossRef] [PubMed] 
14. Bakshi, M.V.; Azimzadeh, O.; Barjaktarovic, Z.; Kempf, S.J.; Merl-Pham, J.; Hauck, S.M.; Buratovic, S.; Eriksson, P.; Atkinson, M.J.; Tapio, S. Total body exposure to low-dose ionizing radiation induces long-term alterations to the liver proteome of neonatally exposed mice. J. Proteome Res. 2015, 14, 366-373. [CrossRef] [PubMed]

15. Bakshi, M.V.; Barjaktarovic, Z.; Azimzadeh, O.; Kempf, S.J.; Merl, J.; Hauck, S.M.; Eriksson, P.; Buratovic, S.; Atkinson, M.J.; Tapio, S. Long-term effects of acute low-dose ionizing radiation on the neonatal mouse heart: A proteomic study. Radiat. Environ. Biophys. 2013, 52, 451-461. [CrossRef] [PubMed]

16. Little, M.P.; Tawn, E.J.; Tzoulaki, I.; Wakeford, R.; Hildebrandt, G.; Paris, F.; Tapio, S.; Elliott, P. Review and meta-analysis of epidemiological associations between low/moderate doses of ionizing radiation and circulatory disease risks, and their possible mechanisms. Radiat. Environ. Biophys. 2010, 49, 139-153. [CrossRef] [PubMed]

17. Azimzadeh, O.; Scherthan, H.; Sarioglu, H.; Barjaktarovic, Z.; Conrad, M.; Vogt, A.; Calzada-Wack, J.; Neff, F.; Aubele, M.; Buske, C.; et al. Rapid proteomic remodeling of cardiac tissue caused by total body ionizing radiation. Proteomics 2011, 11, 3299-3311. [CrossRef] [PubMed]

18. Smith, R.W.; Wang, J.; Mothersill, C.E.; Hinton, T.G.; Aizawa, K.; Seymour, C.B. Proteomic changes in the gills of wild-type and transgenic radiosensitive medaka following exposure to direct irradiation and to X-ray induced bystander signals. Biochim. Biophys. Acta 2011, 1814, 290-298. [CrossRef]

19. Wittbrodt, J.; Shima, A.; Schartl, M. Medaka-A model organism from the far East. Nat. Rev. Genet. 2002, 3, 53-64. [CrossRef]

20. Winn, R.N.; Norris, M.B.; Brayer, K.J.; Torres, C.; Muller, S.L. Detection of mutations in transgenic fish carrying a bacteriophage lambda cII transgene target. Proc. Natl. Acad. Sci. USA 2000, 97, 12655-12660. [CrossRef]

21. Metcalfe, C. Test for predicting carcinogenicity in fish. CRC Rev. Aquat. Sci. 1989, 1, 111-129.

22. Law, J.M. Mechanistic considerations in small fish carcinogenicity testing. Ilar J. 2001, 42, 274-284. [CrossRef] [PubMed]

23. Ding, L.; Kuhne, W.W.; Hinton, D.E.; Song, J.; Dynan, W.S. Quantifiable biomarkers of normal aging in the Japanese medaka fish (Oryzias latipes). PLoS ONE 2010, 5, e13287. [CrossRef] [PubMed]

24. Kasahara, M.; Naruse, K.; Sasaki, S.; Nakatani, Y.; Qu, W.; Ahsan, B.; Yamada, T.; Nagayasu, Y.; Doi, K.; Kasai, Y.; et al. The medaka draft genome and insights into vertebrate genome evolution. Nature 2007, 447, 714-719. [CrossRef] [PubMed]

25. Takeda, H.; Shimada, A. The art of medaka genetics and genomics: What makes them so unique? Annu. Rev. Genet. 2010, 44, 217-241. [CrossRef] [PubMed]

26. Chaze, T.; Hornez, L.; Chambon, C.; Haddad, I.; Vinh, J.; Peyrat, J.P.; Benderitter, M.; Guipaud, O. Serum Proteome Analysis for Profiling Predictive Protein Markers Associated with the Severity of Skin Lesions Induced by Ionizing Radiation. Proteomes 2013, 1, 40-69. [CrossRef] [PubMed]

27. Raman, S.; Maxwell, C.A.; Barcellos-Hoff, M.H.; Parvin, B. Geometric approach to segmentation and protein localization in cell culture assays. J. Microsc. 2007, 225, 22-30. [CrossRef] [PubMed]

28. Ostling, O.; Johanson, K.J. Microelectrophoretic study of radiation-induced DNA damages in individual mammalian cells. Biochem. Biophys. Res. Commun. 1984, 123, 291-298. [CrossRef]

29. Tsyusko, O.; Glenn, T.; Yi, Y.; Joice, G.; Jones, K.; Aizawa, K.; Coughlin, D.; Zimbrick, J.; Hinton, T. Differential genetic responses to ionizing irradiation in individual families of Japanese medaka, Oryzias latipes. Mutat. Res. 2011, 718, 18-23. [CrossRef]

30. Members of the Panel on Euthanasia. AVMA Guidelines for the Euthanasia of Animals, 2013th ed.; American Veterinary Medical Association: Schaumburg, IL, USA, 2013; ISBN 978-1-882691-21-0.

31. Aoki, K.; Perlman, M.; Lim, J.M.; Cantu, R.; Wells, L.; Tiemeyer, M. Dynamic developmental elaboration of N-linked glycan complexity in the Drosophila melanogaster embryo. J. Biol. Chem. 2007, 282, 9127-9142. [CrossRef]

32. Okuda, S.; Watanabe, Y.; Moriya, Y.; Kawano, S.; Yamamoto, T.; Matsumoto, M.; Takami, T.; Kobayashi, D.; Araki, N.; Yoshizawa, A.C.; et al. jPOSTrepo: An international standard data repository for proteomes. Nucleic Acids Res. 2017, 45, D1107-D1111. [CrossRef]

33. Weatherly, D.B.; Atwood, J.A., 3rd; Minning, T.A.; Cavola, C.; Tarleton, R.L.; Orlando, R. A Heuristic method for assigning a false-discovery rate for protein identifications from Mascot database search results. Mol. Cell. Proteom. 2005, 4, 762-772. [CrossRef] [PubMed] 
34. Cottrell, J.S. Protein identification using MS/MS data. J. Proteom. 2011, 74, 1842-1851. [CrossRef] [PubMed]

35. Lubec, G.; Afjehi-Sadat, L.; Yang, J.W.; John, J.P. Searching for hypothetical proteins: Theory and practice based upon original data and literature. Prog. Neurobiol. 2005, 77, 90-127. [CrossRef] [PubMed]

36. Alcantara-Martinez, N.; Figueroa-Martinez, F.; Rivera-Cabrera, F.; Gutierrez-Sanchez, G.; Volke-Sepulveda, T. An endophytic strain of Methylobacterium sp. increases arsenate tolerance in Acacia farnesiana (L.) Willd: A proteomic approach. Sci. Total Environ. 2018, 625, 762-774. [CrossRef] [PubMed]

37. Volke-Sepulveda, T.; Salgado-Bautista, D.; Bergmann, C.; Wells, L.; Gutierrez-Sanchez, G.; Favela-Torres, E. Secretomic Insight into Glucose Metabolism of Aspergillus brasiliensis in Solid-State Fermentation. J. Proteome Res. 2016, 15, 3856-3871. [CrossRef] [PubMed]

38. Donato, R. S100: A multigenic family of calcium-modulated proteins of the EF-hand type with intracellular and extracellular functional roles. Int. J. Biochem. Cell Biol. 2001, 33, 637-668. [CrossRef]

39. Orre, L.M.; Pernemalm, M.; Lengqvist, J.; Lewensohn, R.; Lehtio, J. Up-regulation, modification, and translocation of S100A6 induced by exposure to ionizing radiation revealed by proteomics profiling. Mol. Cell. Proteom. 2007, 6, 2122-2131. [CrossRef]

40. Braunstein, S.; Badura, M.L.; Xi, Q.; Formenti, S.C.; Schneider, R.J. Regulation of protein synthesis by ionizing radiation. Mol. Cell. Biol. 2009, 29, 5645-5656. [CrossRef]

41. Sekihara, K.; Saitoh, K.; Yang, H.; Kawashima, H.; Kazuno, S.; Kikkawa, M.; Arai, H.; Miida, T.; Hayashi, N.; Sasai, K.; et al. Low-dose ionizing radiation exposure represses the cell cycle and protein synthesis pathways in in vitro human primary keratinocytes and U937 cell lines. PLoS ONE 2018, 13, e0199117. [CrossRef]

42. Zhao, Y.; Tan, M.; Liu, X.; Xiong, X.; Sun, Y. Inactivation of ribosomal protein S27-like confers radiosensitivity via the Mdm2-p53 and Mdm2-MRN-ATM axes. Cell Death Dis. 2018, 9, 145. [CrossRef]

43. Tian, W.N.; Braunstein, L.D.; Pang, J.; Stuhlmeier, K.M.; Xi, Q.C.; Tian, X.; Stanton, R.C. Importance of glucose-6-phosphate dehydrogenase activity for cell growth. J. Biol. Chem. 1998, 273, 10609-10617. [CrossRef] [PubMed]

44. Saha, G.B. Physics and Radiobiology of Nuclear Medicine, 4th ed.; Springer: New York, NY, USA; London, UK, 2012.

45. Jovine, L.; Qi, H.; Williams, Z.; Litscher, E.; Wassarman, P.M. The ZP domain is a conserved module for polymerization of extracellular proteins. Nat. Cell Biol. 2002, 4, 457-461. [CrossRef] [PubMed] 